\title{
LA «NIÑA BONITA». IMÁGENES DE LA VIOLENCIA (Y NO VIOLENCIA) DE LA SEGUNDA REPÚBLICA ESPAÑOLA EN EL CINE
}

\author{
THE «NINA BONITA». IMAGES OF THE VIOLENCE \\ (AND NON-VIOLENCE) OF THE SPANISH SECOND \\ REPUBLIC IN CINEMA
}

Igor Barrenetxea Marañón*

Universidad del País Vasco / Basque Country University (UPV/EHU),

Leioa, España

RESUMEN: La historia de la Segunda República española ha venido jalonada de mitos, falsedades, prejuicios y representaciones que han configurado parte de su memoria. Este artículo pretende bucear y analizar, desde las fuentes visuales, el imaginario colectivo que el cine ha construido de ella. Desde luego, no es monolítico, sino que ha ido evolucionando a la par que se han ido mostrando cambios en la sociedad española, desde la denostación del periodo, durante el franquismo, hasta un proceso de idealización que ha ido germinando durante la democracia. Sin embargo, vamos a hacer hincapié, principalmente, en la vinculación que se ha dado de la República con la violencia política o anticlerical que, en buena medida, ha determinado, a pesar de las aportaciones que se han hecho por parte de la historiografía, su imagen negativa, la cual ha venido más ligada a los debates sobre la causa y el origen de la Guerra Civil española, y los efectos de la represión, que por una tamizada mirada del periodo.

PALABRAS CLAVE: Segunda República. Memoria. Violencia. Cine.

ABSTRACT: The history of the Second Spanish Republic has been marked by myth, deceit, prejudices and representations which have conformed part of its memory. This article intends to dive in and analyse, from visual sources, the collective imaginary which cinema has built out of it. It is, of course, not monolithic but, rather, it has evolved at the same time that changes in Spanish society have been displayed; from the revilement of the period during Franco's regime, to a process of idealisation which has germinated during democracy. However, we are going to stress, mostly, the correlation which has been given of the Republic with the political or anticlerical violence that, despite the contributions of historiography, has in great length determined its negative image, more influenced by the discussions about the causes and origins of the Spanish Civil War and the effects of repression than by a properly weighed up look of the period.

KEYWORDS: Second Republic. Memory. Violence. Cinema.

\footnotetext{
* Correspondencia a: Igor Barrenetxea Marañón. c/ Cortes 20, 3C 48003 Bilbao (Bizkaia) - ibm@bezeroak.euskaltel.es https://orcid.org/0000-0003-1044-5276
}

Cómo citar: Barrenetxea Marañon, Igor (2019). «La "niña bonita". Imágenes de la violencia (y no violencia) de la Segunda República española en el cine»; Historia Contemporánea, 59, 235-267. (https://doi.org/10.1387/hc.18865).

Recibido: 12 diciembre, 2017; aceptado: 25 septiembre, 2018.

ISSN 1130-2402 - eISSN 2340-0277 / (C) 2019 UPV/EHU 
«La insoportable gravedad de la violencia, la amenaza de la revolución social, la complicidad o la ineptitud de los gobernantes, la ofensiva del fascismo, la deslealtad de los militares, la maldad, en definitiva, de muchos hombres, se convirtieron en el eje de las explicaciones de la guerra, un acontecimiento dramático y necesario para restaurar la España católica o destruir la democracia.» ${ }^{1}$

«Las violencias de la primavera de 1936 , como las de todo el periodo republicano, no deben interpretarse como la causa de la Guerra Civil, sino como la manifestación inmediata y notoria de un estado de agitación social y de lucha política que se conecta con la dinámica de enfrentamiento entre proyectos reaccionarios, reformistas y revolucionarios que estaba sufriendo España desde la primera posguerra mundial.» $^{2}$

\section{Introducción}

El cine es una fuente de la Historia, constituye un elemento cultural esencial para comprender nuestras sociedades (tanto por lo que refleja de ellas como por la manera en que es recibido), una suerte de historia no oficial que conforma nuestro imaginario social ${ }^{3}$. Pues este imaginario no se constituye únicamente por experiencias sino, en el caso de las generaciones que no vivieron tales acontecimientos, por la influencia de la historiografía, la literatura y, por supuesto, el cine y la televisión.

En este estudio, nos adentraremos en la influencia del séptimo arte en la configuración de la imagen de la violencia (o ausencia de ella) del periodo de la Segunda República española (1931-1936), a través de una amplia muestra de una treintena de películas que abarca desde el franquismo a la democracia ${ }^{4}$.

Los trabajos, estudios y publicaciones como los de Josefina Cuesta y Paloma Aguilar, o los coordinados por Manuel Morales o Ángeles Egido, sin ir más lejos, nos han dado una cada vez más acabada memoria de la

1 Cruz, 2006, p. 332.

2 González Calleja, 2015a, p. 307.

3 Ferro, 1995; Montero y Paz, 1995; Rosenstone, 1997, Lagny, 1997 y Burke, 2001.

${ }^{4}$ Zunzunegui, Castro de Paz y Pérez Perucha (dirs), 2005 y Rubio, 2007. 
época ${ }^{5}$. Pero es cierto que el proceso vino marcado por una serie de hechos que desembocaron en uno de los acontecimientos más destacados, por traumático, y dolorosos, de la historia española del siglo xx: la Guerra Civil (1936-1939). Y muchos han sido los efectos destructivos de la contienda que han contaminado la visión que se ha realizado de la época anterior. Su origen no fue inevitable, tampoco fue provocada o iniciada por los republicanos en 1934 y el hecho de que el Frente Popular, tal y como se ha mostrado recientemente, no ganara limpiamente las elecciones de febrero de 1936 no justificaba tampoco, específicamente, como los mismos autores establecen ${ }^{6}$, el fallido golpe perpetrado por los militares. El recuerdo es, además, una faceta activa de la memoria social ${ }^{7}$. Y esta memoria contribuye de forma significativa, por un lado, a valorar el profundo, o superficial, proceso de maduración adquirido en la sociedad y, por otro, a entender ese pasado ${ }^{8}$. De hecho, Rosenstone llega más lejos y afirma que se establece una nueva relación con nuestro ayer ${ }^{9}$.

La historiografía ha ido abriéndose paso a la hora de abordar el tema de la República. Nunca el panorama ha sido tan amplio a la hora de encontrarnos con variada y enriquecedora bibliografía que nos permite desvelar los complejos entresijos sociales, económicos o políticos de lo sucedido $^{10}$. Se ha ido respondiendo a las preguntas de ¿por qué? y ¿cómo? y, aún así, eso no ha evitado que en este proceso de investigación haya quien pretende dogmatizar el pasado. La Segunda República, en todo caso, ha quedado a la sombra de la contienda como un periodo maldito, entre la idealización y el oscurantismo. Y colindante a la Historia sabemos que brotan los mitos.

Esos mitos surgen de una necesidad de simplificar los acontecimientos y dotarles de fatalidad o glorificación (dependiendo de los intereses ideológicos que los defiendan y garanticen su perdurabilidad) y se refuerzan en la medida en la que son enfatizados a través de los medios de comunicación y la literatura ${ }^{11}$.

5 Aguilar Fernández, 1996; Morales Muñoz, 2004; Egido león, 2006; Ballarín y Ledesma, 2007 y Cuesta, 2008.

6 Álvarez Tardío y Villa García, 2017.

7 Fentress y Wickham, 2003.

${ }^{8}$ Ricoeur, 1999 y Halbwachs, 2004.

9 Rosenstone, 1997, p. 20.

10 González Calleja y Ribagorda, 2017.

11 Camarero, 2002. 
Por ello, la tesis de este artículo plantea mostrar la codificación que se ha hecho del periodo republicano en relación a la violencia desde el cine $^{12}$, y contrastar el discurso o narrativa audiovisual ${ }^{13}$ con la historiografía para verificar si fue así y de qué manera esto influye o nos determina a la hora de calificar o describir el periodo como de turbulento o justificativo de la contienda, y la necesidad que tenemos de valorar dichos axiomas. Como apunta Todorov, los acontecimientos pueden ser traídos a colación de forma literal o ejemplar ${ }^{14}$, y lo que él aconseja es que sean vistos desde este último.

\section{La representación del origen de la Segunda República en el cine}

Aunque abordamos la representación de la(s) violencia(s), los orígenes de la Segunda República, paradójicamente, vienen salpicados por una estampa bucólica que no perduraría: los madrileños llenos de alegría invadiendo las calles en una celebración multitudinaria pacífica, que se emularía en muchas otras ciudades del país.

Las elecciones del 12 de abril de 1931 se convirtieron en un plebiscito entre monarquía y república, y la monarquía acabó perdiéndolo. En la mayoría de las grandes ciudades ganaron las candidaturas republicanas o de izquierdas. Y, por consecuencia, el 14 de abril en el municipio guipuzcoano de Eibar se proclamó la Segunda República.

Pocas veces un cambio de régimen había sido llevado con una actitud tan cívica, desmontándose sin derramar una gota de sangre ${ }^{15}$.

Sin ir más lejos, Alberto Reig Tapia ${ }^{16}$ analiza las imágenes documentales que serán muy utilizadas en diversas producciones, tanto a nivel documental como de ficción, para ilustrar el origen popular (no revolucionario ni violento) de esta república de ciudadanos, tal como la denomina Sandie Holguín ${ }^{17}$.

12 Debido a cuestiones de espacio no me he centrado en la recepción que daría para otro artículo, a pesar de que para el periodo del franquismo los datos no son fiables, sobre este tema: Camporesi, 1994 y Gubern et al., 2015.

13 Montero y Paz, 2013 y Rosenstone, 2014.

14 Todorov, 2000, p. 30.

15 Gil Pecharromán, 2002; Cruz, 2006; Cruz, 2014 y González Calleja, Cobo Romero, Martínez Rus y Sánchez Pérez, 2015.

16 Reig Tapia, 2006a, p. 139.

17 Holguín, 2003. 
El proyecto republicano de 1931 se activó como un ideal regenerador en todos los órdenes de la sociedad. Sus ambiciosas metas pretendían modernizar España, pero venían a encontrarse de frente con aquellos que entendían el país desde postulados más conservadores y tradicionales, que se habían quedado confundidos ante la suerte de hechos que habían acabado con la monarquía de la Restauración, además de aquellos más radicales que pretendían realizar esa transformación de manera inmediata.

El impulso reformista republicano fue muy amplio y abarcó muy diversos ámbitos: educativo, laboral, constitucional, militar, religioso, agrario, etc., pero eso no significó que no estuviera exento de confrontaciones porque para algunos estas reformas fueron demasiado audaces, para otros, en cambio, tales procesos eran demasiado lentos y otros los vieron como una amenaza a sus formas de vida o a su status social.

La sociedad española se hallaba en un profundo proceso de transformación, como Europa, y eso se reflejaba en un rico florecimiento cultural (coincidiría con la edad de plata de la literatura española), también lleno de contradicciones, enfrentándose modernidad y tradicionalismo, democracia y autoritarismo, y, cómo no, fascismo versus comunismo, difíciles de equilibrar ${ }^{18}$. Pero, principalmente, se le unió un factor muy determinante: una falta de madurez política, en un país sin tradición democrática, que dio lugar a un profundo temor a los extremismos y una pugna entre el miedo a la revolución y a la contrarrevolución ${ }^{19}$. Sin embargo, aunque el quinquenio dio mucho de sí, tanto en sus aspectos de avance, retroceso y conflictivos (desde la intentona golpista de Sanjurjo, en 1932, pasando por la revolución de Asturias de 1934, hasta la victoria electoral del Frente Popular, en 1936), no son demasiados los filmes que abordan directamente el periodo y cuando lo hacen vienen marcados, en muchos casos, por su relación con el trauma surgido de la devastadora y cruenta Guerra Civil.

El primer gran hito de la República fue su instauración pacífica, frente a otros regímenes precedentes en España, en la tradición liberal de los pronunciamientos militares del siglo XIX. Y en su traslación a la gran pantalla nos vamos a encontrar con un puñado de ilustrativos filmes (sin pretender ser exhaustivo) como son: Mi calle (1960), de Edgar Neville, Un

\footnotetext{
18 Aguado y Ramos, 2002.

19 Juliá, 2005; Álvarez Tardío y Villa García, 2010; Del Rey, 2011 y Álvarez Tardío y Del Rey, 2012.
} 
puente sobre el tiempo (1964), de José Luis Merino, Las últimas horas (1965), de Santos Alcocer, Pascual Duarte (1975), de Ricardo Franco, Borrasca (1977), de Miguel Ángel Rivas, Mi hija Hildegart (1977), de Fernando Fernán Gómez, Tierra de rastrojos (1979), de Antonio García Cano, La plaza del diamante (1982) (versión para el cine), Réquiem por un campesino español (1986), ambas de Francesc Betriu, y Belle Époque (1992), de Fernando Trueba ${ }^{20}$.

De entre las escasas películas franquistas que se refieren al advenimiento de la República cabe incidir en Mi calle (1960). El filme retrata la historia de los vecinos de una calle de Madrid desde 1906 hasta 1939, en donde se describen las vivencias, esperanzas y deseos de diferentes personajes. La imagen que se ofrece de la Segunda República, en este amplio recorrido, es muy puntual, se alude a su entusiasta llegada pero, tras su implantación, las características que se presentan de ella son marcadamente negativas. Así nos encontraremos, por ejemplo, con la figura del republicano desencantado con sus ideales, la República «prometía ser generosa y eficaz [...]», y acaba presa de aquellos sembraderos de discordia. La época acaba en una «revolución» y, por añadidura, en «guerra civil» y, por supuesto, se destaca la criminalidad de parte de sus miembros y simpatizantes ${ }^{21}$.

Unos pocos años después, coincidiendo con la celebración de los 25 años de paz, en Un puente sobre el tiempo (1964), homenaje a los alféreces provisionales, uno de los protagonistas describe la llegada de la República despectivamente como «un jolgorio de verbena», y matiza: «aunque en realidad fue una satánica alianza de todos los seculares enemigos del alma nacional». Queda claro que, a pesar de que se ilustra el momento con las imágenes documentales que se conservan de unas calles de Madrid llenas de gentes alegres por su instauración, su lectura es mordazmente desacreditadora.

La siguiente alusión manifiesta sería en Las últimas horas (1965). Producida con escasos medios y de escasa calidad técnica, en ella se nos desvelan las causas del advenimiento republicano. La trama discurre, precisamente, en los últimos compases del fin de la monarquía de Al-

${ }^{20}$ En Raza también se alude en un fugaz plano en el que aparece la portada del periódico Ahora, con el neutro titular «Se ha proclamado la República española», seguido de otro en el que se señala que han sido quemados diez conventos, lo que muestra, de buenas a primeras, el cariz negativo del régimen.

21 Viadero Carral, 2016, p. 153. 
fonso XIII, tras conocerse los resultados de las elecciones municipales del 12 de abril que desembocaron en su exilio ${ }^{22}$.

La historia gira en torno a una joven pareja, Almudena e Isidro. Los personajes y caracterización de los republicanos contienen etiquetas muy negativas (son los «enemigos»), frente a la España tradicional.

La trama intenta ser una crítica al sistema liberal y panegírico de la figura del monarca Alfonso XIII. La aceptación de la República es justificada para evitar una «revolución sangrienta» y una «fratricida Guerra Civil», que sutilmente se anticipa. Por lo tanto, la visión que hace del periodo, en ambos casos, es de resignación para evitar un mal mayor, aunque eso no sea posible porque, finalmente, se llegará a producir la guerra, de la cual solo la República es responsable irremediable.

En cambio, las siguientes películas fueron rodadas durante la democracia y, por lo tanto, su perspectiva es menos funesta, aunque conservan un tono melancólico. Sin embargo, el contexto político social enfatizaba aprender de ese pasado.

En los filmes Pascual Duarte (1975) y Borrasca (1977) la caracterización de la llegada de la República es anecdótica y escasamente incidental. La película de Ricardo Franco anuncia el advenimiento republicano con un aire triunfal, algo que tuvo que sortear el final de la censura, puesto que se ofrecía una visión positiva de este régimen sin ningún apóstrofe negativo. En la de Rivas, de talante anarquista, la llegada de la República se produce al cierre ya que la trama denuncia el caciquismo de la época de la Restauración. Para el director, la instauración de la República es más de lo mismo y no significa ningún cambio de las inercias políticas españolas.

Habría que aguardar al estreno de Mi hija Hildegart (1977), para valorar la época democrática desde una visión menos negativa. El largometraje retrata la vida de Aurora Rodríguez, una conocida activista feminista. Para lograr su objetivo concibió a su hija Hildegart, pero cuando creyó que traicionaba su ideal, trastornada, acabó asesinándola, en 1935. El controvertido y verídico hecho sirvió a Fernán Gómez, en plena Transición, para advertirnos sobre el fanatismo ideológico y mostrando, de este modo, la maduración política y social de los españoles en la década anterior $^{23}$.

22 Ben Ami, 1990.

23 Mainer y Juliá, 2000 y Trenzado, 1999. 
La instantánea de la llegada de la República se reproduce en una breve escena, mientras la protagonista, Aurora, se encuentra en la cárcel, a punto de ser juzgada por su crimen, donde rememora junto al periodista Eduardo de Guzmán ${ }^{24}$ el día en que se produjo. El recuerdo de aquel momento llena de alegría momentánea a ambos personajes, tras lo cual se reprocha a la República haber traicionado su espíritu. Si bien, mostrándonos que fue acogido con felicidad por parte de los ciudadanos españoles. En suma, se presenta como una apuesta de cambio social y político frustrada, incapaz de alcanzar su propio hito transformador, aunque no explica por qué fue así.

En el siguiente filme, Tierra de rastrojos (1979), se radiografía la dura vida de una familia campesina andaluza desde principios de siglo hasta los años 50, y también se ofrece una interesante visión. El recuerdo de la llegada de la República se inserta, casi al final, en el marco de una elipsis temporal cuando dos personajes secundarios, el zapatero del pueblo y el dueño de la taberna, rememoran ese episodio tras la Guerra Civil. Para ellos, la República implica un periodo perdido e irrecuperable, el único marco alegre de sus vidas. Por lo tanto, la etapa se presenta como un chispazo de ilusión y esperanza que se trunca tan rápidamente como aparece.

Los últimos trabajos en los que se muestra el impacto que produjo la llegada de la República perfilan nuevos ingredientes como La plaza del diamante (1982), Réquiem por un campesino español (1985) y la oscarizada Belle Époque (1992).

En la adaptación que se hizo de la serie televisiva, La plaza del diamante (1982), inspirada en la novela La plaça del Diamant de Mercè Rodoreda, se relata la vida de Natalia (La Colometa) en un barrio de Barcelona $^{25}$. La llegada de la República se marca a través de una manifestación pacífica, tras conocerse los resultados municipales que llevan al fin de la monarquía, donde ondean banderas tricolores y señeras, mientras se canta en catalán la Marsellesa. Así mismo, se expresa la posterior alegría familiar provocada por tal alegre acontecimiento celebrado con champán y con la suelta de unas palomas que han criado. La República significa cambio, promesas y libertad. Estos elementos se unen bien con lo que señalan Moreno y Núñez Seixas, que tras el fin de la monarquía se produjo una

${ }^{24}$ De Guzmán, 1956. Se inspira en su novela.

25 Mirambel, 1994, pp. 1-10. 
«irrupción callejera de la bandera nacional republicana» ${ }^{26}$. Sin embargo, no se ofrecen razones para explicar el cierre de dicha etapa.

En el otro largometraje de Betriu, adaptación de la novela homónima de $\operatorname{Sender}^{27}$, se retrata la vida de un campesino, Antonio «el del Molino», desde su nacimiento hasta su asesinato con la entrada de las tropas falangistas a la localidad, en 1936. El anuncio de la victoria de las candidaturas republicanas es presentado, una vez más, con felicidad por los ciudadanos del pueblo, y pesadumbre por los representantes del viejo orden conservador. Por lo tanto, se recrea con una desbordante ilusión, con un marcado reformismo y una común esperanza de mejora social.

El último largometraje que describe este marco histórico, Belle Époque (1992) discurre, en cambio, en los meses previos a su instauración.

El retrato irónico que realiza Trueba nos habla de una España que sostiene profundos rasgos arcaicos, que contrastan con un liberalismo en ciernes. En esta ocasión, la llegada de la República no será, como en Las últimas horas, el preludio de una tragedia, sino de otro tiempo lleno de expectativas e ilusiones.

En síntesis, a pesar de la escasez e irregular calidad de películas en las que se recrea el advenimiento de la República, se observa una evolución. En la etapa del franquismo, se presenta desde una mirada crítica, y aunque la República fue demonizada por el régimen franquista, sí muestra que llegó de forma pacífica y no abrupta, como sucederá con su trágico final, aunque es utilizado como el preludio inevitable de la guerra. En cambio, en la etapa siguiente, con la Transición y en plena democracia, nos encontramos con algunos elementos singulares. Se revela como una esperanza fallida, que llegó de forma popular y cívica, y fue recibida con esperanza y alegría por las fuerzas progresistas y reformistas del país, salvo en el caso de Borrasca, coincidiendo en el marco de una época reflexiva que aspira a aprender de los errores pasados ${ }^{28}$. Así que, mayormente, la República, tanto por sus detractores como por sus defensores, se concita como un régimen fallido. Los primeros, porque consideraban que ese proyecto liberal era ya, de por sí, un error por no responder a las esencias patrias y

${ }^{26}$ Moreno Luzón y Núñez Seixas, 2013, p. 71. En realidad, es muy parecida a la rojigualda salvo porque se le añadió una franja morada que encarnaba a los comuneros de Castilla y el mito que estos encarnaban para el liberalismo

27 Sender, 2006.

${ }^{28}$ Mainer y Juliá, 2000, p. 55. 
permitir que los radicalismos tomaran las riendas del país, y los segundos, porque no llegó a cuajar su ideal ante la oposición de las fuerzas conservadoras y en otros casos, aunque sin saber por qué, por su incapacidad de acabar triunfando.

\section{La mirada franquista de la violencia republicana}

Tras el anuncio del fin de la guerra por parte de Franco, el 1 de abril de 1939, la República y sus vestigios fueron clausurados. Aunque la rebelión militar nació de una presunta intención de restaurar el orden, y no de derribar al régimen republicano, la contienda cambió este plan. Los bandos enfrentados se definieron de una manera antitética y la propaganda jugó una baza importante a la hora de desatar los odios y las frustraciones vividas en los años anteriores. Así que, a su conclusión, la línea que distinguiría a vencedores y vencidos sería muy nítida.

El Nuevo Estado franquista nunca buscó la reconciliación sino más bien encontró la presunta oportunidad de devolver a España su rancio y presunto brillo imperial y depurar y consagrarse a recuperar las esencias de la nación. El liberalismo y lo que este (en parte) había traído consigo se consideraba el culpable de que la sociedad se hubiera fragmentado, debilitado y, finalmente, caído en el abismo del comunismo ${ }^{29}$.

Una nueva legitimidad nacería de la victoria en la guerra y, por lo tanto, la República que, como se ha visto, en sus orígenes fue proclamada de forma pacífica por la voluntad popular, fue clausurada ${ }^{30}$. En los años 40 y 50 la mención en el cine del periodo fue casi inexistente y adquiriría siempre unos rasgos malignos. El discurso cinematográfico se cuidó de que el liberalismo y el anticlericalismo cargasen con el peso de la hecatombe dramática de la lucha fratricida ${ }^{31}$.

Pero, sobre todo, se enfatizó y mucho la turbulencia revolucionaria y la violencia política como si fuera un periodo oscuro, el culmen de un desastre anunciado, como si previamente (antes del Frente Popular) no se hubiese dado jamás nada parecido y la República y solo la Repú-

\footnotetext{
29 Moradiellos, 2000; Moradiellos, 2004; Juliá, 2006; Gil Pecharromán, 2008; Riquer, 2010 y Box, 2010.

30 Cazorla Sánchez, 2008.

31 Caparrós Lera, 1983; Castro de Paz, 2002; Crusells, 2006 y Sánchez-Biosca, 2006.
} 
blica fuera responsable directo de ella ${ }^{32}$. Películas como Gracia y Justicia (1940), de Julián Torremocha, ambientada en unos difusos años 30, advertían de la corrupción del sistema político liberal; o Fortunato (1941), de Fernando Delgado, adaptación de una obra teatral de los hermanos Álvarez Quintero, que denuncia el clientelismo y la miseria social, son dos claros ejemplos de ello.

No obstante, en esta última, los censores se cuidaron bien de señalar que la historia transcurría en 1934, para identificarla con la nefasta República, y para no confundirla con el contexto del franquismo ${ }^{33}$. Incluso, de forma metafórica, aludirá a la violencia [republicana] y los sacrificios que ha de hacer un padre por su familia, cuando Fortunato (irónico nombre para un hombre tan desafortunado) ha de verse obligado a convertirse en una diana humana, para salvar a su familia de la miseria.

A estas tramas habría que sumar, por supuesto, aquellas denominadas películas de Cruzada ${ }^{34}$, cuya temática principal era la guerra, y que caracterizarán el periodo republicano como un marco de violencia, horror, persecución religiosa, caos y desorden social. Todo ello, claro, bajo la terrible amenaza del comunismo con el que se identifica, indiscriminadamente, a las izquierdas y a las fuerzas republicanas ${ }^{35}$.

En la producción hispano-italiana Sin novedad en el Alcázar (1940), de Augusto Genina, rodada al poco de acabar las hostilidades, quedaba claro cuál iba a ser el discurso dominante. Nada más empezar la épica historia, se reproduce la encendida y exagerada ponencia de Calvo Sotelo en el parlamento donde reprocha a la República por su inacción ante los 300 muertos, más de 1.000 heridos, cientos de huelgas y, por todas partes, «desorden, pillaje, saqueos, destrucción». Posteriormente, aparecerá la noticia de su vil asesinato. Deja, por lo tanto, bien claro que la única manera de actuar de los militares es defender a la patria de tal anarquía, mostrando, así, una República incapaz de mantener el orden y que la violencia política campaba a sus anchas.

32 Juliá, 2017, p. 17. «Por lo demás, el recurso a la violencia política fue habitual en las luchas políticas del siglo XIX». Lo que reflejaba que en la época republicana tuvo su continuismo, no nació en ella.

33 AGA, Cultura, Caja 21/4456, dossier «Fortunato».

34 Sánchez-Biosca, 2006, p. 147.

35 Aunque conocemos bastante bien la debilidad del Partido Comunista y las tensiones en el seno del PSOE. Cf. Blas, 1978; Juliá, 1977; Contreras, 1981; Cruz, 1987; Macarro, 2012 y Rees, 2012. 
Dos de las películas más importantes del periodo, por diferentes motivos acompañando a la anterior, serían Raza (1942), de José Luís Sáenz de Heredia, y Rojo y negro (1942), de Carlos Arévalo. Aunque ambas cuentan con numerosos estudios, lo que interesa subrayar es su caracterización del periodo republicano que casa con lo que hemos señalado, presentado a través de elocuentes imágenes y los diálogos de los personajes: un gobierno caótico, violencia política y anticlerical y revolución ${ }^{36}$.

Pero eso se lleva a cabo de una manera muy sutil, sin extenderse demasiado, casi como una transición entre el fin de la República y el inicio de la Guerra Civil, un aspecto que ayuda a descalificar al quinquenio democrático y sustituirlo por una imagen no solo borrosa sino de violencia imparable, que solo pudo ser confrontada con una solución autoritaria y conservadora. Más concretamente, en el filme de Arévalo ni tan siquiera se nos muestra la violencia, sino que esta se ilustra a través de una serie de recortes de prensa (como si fuesen datos taxativos), lo que codifica la idea de que la época fue un marco de inestabilidad y, sobre todo, de crímenes violentos y ataques a la Iglesia. Paradójicamente, parte de ese pistolerismo estuvo protagonizado por Falange, a la que se rinde tributo en la propia película.

Así, la violencia más atroz se mostrará al final, ya en plena contienda, con la violación y posterior asesinato de la protagonista, por parte de milicianos, como si fuese la consecuencia lógica de la situación previa republicana.

Además, al situar el contexto inicial en 1936, como en otros filmes franquistas, subraya como la violencia nació en la etapa del Frente Popular, sin mencionar las etapas previas ni, por supuesto, realizar una valoración crítica o autocrítica del uso de la violencia por parte de los partidos y organizaciones implicadas (dando a entender que esta solo procedía de un lado, el de las izquierdas revolucionarias).

Todo ello mostraba que había una justificación para el golpe militar porque la República no solo no atajaba tal situación de caos sino que lo provocaba. Y los militares (aunque solo una parte) reaccionaron para frenar una revolución en ciernes.

Otra película digna de destacar del periodo, por su rareza y originalidad, es Vida en sombra (1948), de Llobet Gracia. Se trata de un homenaje al cine. El modo en el que se procede a ilustrar el cambio de época reside en un recurso elíptico muy simple, pero recurrente por su simbolismo. Se

${ }^{36}$ Gubern, 1985, pp. 61-75; Elena, 1997, pp. 61-78 y Alzola Cerero, 2017, pp. 39-52. 
cambia un crucifijo colgado en una pared por la Dama República mientras se escuchan de fondo unas voces infantiles recitando las tablas de multiplicar. Sin embargo, en este marco es cuando la pareja protagonista, Carlos y Ana, se reencuentran, tras años de separación, y se acaban casando. Por lo tanto, el contexto no se ve jalonado por violencias (salvo que la victoria del Frente Popular retrasa el proyecto de Carlos de convertirse en director de cine), al contrario, sino de imágenes de la pareja en la playa y el anuncio de que ella está embarazada. Si bien, su idilio acabará, finalmente, roto, como es de rigor, por el inicio de la contienda.

Por todo ello, el periodo se muestra de forma bastante apacible, sin ninguna imagen vinculada a la violencia salvo cuando estalla la guerra. Claro que por este y otros motivos, la censura lo orilló y lo clasificó de tercera categoría, a pesar de los múltiples intentos del director por que se la cambiasen, ya que eso le auguraba una escasa comercialización. Y no sería estrenada hasta 1953 en programas dobles ${ }^{37}$.

Sin duda, un filme vinculado al cine de cruzada, aunque con matices propios, fue ;El santuario no se rinde! (1949), de Arturo Ruiz Castillo, en línea al mito del Alcázar. En este caso, se cuenta la heroica defensa del Santuario de Santa María de la Cabeza, en Andújar, por parte de un grupo de guardias civiles y civiles huyendo de la violencia de las izquierdas. Las escenas dedicadas a la Segunda República son escuetas en su arranque, pero vienen a estar jalonadas de disturbios de carácter social. Se ofrece, al final, un planteamiento pretendidamente conciliador, que no tendrá influencia alguna en otros filmes posteriores, contra la cruel y brutal guerra. Este es, ante todo, un homenaje a la Guardia Civil (sublevada) y a un espíritu inusual dignificador de lo español, independientemente del bando (contra el comunismo extranjerizante) ${ }^{38}$.

En la década siguiente, el modo de caracterizar el marco republicano se vería reducido a los maniqueísmos impuestos por la dictadura.

Así, en Cerca del cielo (1951) de Mariano Pombo y Domingo Viladomat, se narra desde un punto de vista hagiográfico la biografía del obispo de Teruel, Anselmo Polanco, desde su llegada en 1935, hasta su asesinato en 1938.

El periodo anterior a la guerra se va a caracterizar por una omisión del contexto (la República es denominada como «ese régimen en el que es un

37 Sánchez-Biosca, 2006, p. 164.

38 Ibídem., pp. 158-164. 
delito tener creencias») y por varios momentos de violencia puntuales y significativos. Como cuando un tirador oculto abre fuego desde un campanario a un grupo de manifestantes del Frente Popular (es un comunista que busca exacerbar los ánimos contra la Iglesia), o cuando otro comunista intenta atentar contra el propio obispo. Finalmente, una masa popular (de milicianos) sin identificar provocará el inicio de las hostilidades. La violencia política, por tanto, es ejercida siempre de forma artera por los comunistas, y los militares se presentan, en este caso, como guardianes del orden junto a la institución eclesiástica.

Tres años más tarde se estrenaría Lo que nunca muere (1954), de Julio Salvador. Su trama, basada en la novela radiofónica del mismo nombre, traza la historia de una rencilla familiar que llega a separar a dos hermanos, disponiéndoles a cada uno a luchar en bandos opuestos. El tiempo de la democracia se presenta como un tiempo de caos, gobiernos irresponsables, miseria, violencia y un desprecio a los militares, que es lo que marca el distanciamiento entre los dos hermanos. De nuevo, hay un descrédito total de la República que se resume en su propia inestabilidad y radicalismo.

Tales axiomas negativos no van a modificarse en La paz empieza nunca (1960), de León Klimowsky. Basada en la novela homónima de Emilio Romero, cuenta la trayectoria personal de un joven falangista, López, desde que da comienzo la Guerra Civil hasta los años 50. En la España frentepopulista de 1936, López se presenta formando parte de las nobles actividades de un grupo de falangistas. Sin embargo, sus enemigos no son tan caballerosos y actúan de forma despiadada.

Así, cuando entran a repartir panfletos en un bar, en la jornada electoral, se ven obligados a salir corriendo, y temiendo por sus vidas, se suben al coche en el que han llegado, escuchándose disparos tras ellos. $\mathrm{O}$, en otra escena, unos izquierdistas intentan asesinarles a plena luz del día, mientras están con sus parejas, disparándoles desde un coche. Además de la violencia política de las izquierdas se desvela la violencia anticlerical reinante en el incendio provocado de una iglesia, incitada por un comunista.

Aunque el discurso cinematográfico pareció ir suavizándose respecto al perfil de los bandos enfrentados, no sucedió así en el modo en que se muestra este tiempo. En Un puente sobre el tiempo (1964), la responsabilidad de la guerra y la violencia sigue volviendo a recaer en la República, aunque en este caso identificada con una especie de República soviética. La trama nos cuenta como un joven norteamericano, Javier 
López Cromwell, hijo de un antiguo alférez provisional y periodista, es encomendado a llevar a cabo un reportaje sobre la lucha sostenida contra el comunismo. Para ello, establece contacto con los amigos de su padre, muerto 25 años atrás durante la Guerra Civil, con el fin de entender el porqué de su causa. La historia se convierte, de este modo, en una revisión nostálgica sobre una romántica Cruzada española contra el denostado peligro soviético, del cual solo España ha logrado salir victoriosa y del que las nuevas generaciones, sobre todo las educadas en el extranjero, saben tan poco.

La República queda descrita en el periodo posterior a febrero de 1936 (gobierno del Frente Popular) como una época de incendios, muertos, cientos de heridos, docenas de huelgas, ocupación de fincas, bombas, etc., ilustrado con imágenes documentales. Ante tales evidencias, se señalará simplistamente que un país no puede vivir en «anarquía» y de ahí que los militares tuvieran que tomar cartas en el asunto.

En suma, como tan indicativamente sintetiza Carlos F. Heredero, en los años 50 y 60, la Guerra Fría sentaría la «relectura de la rebelión militar, que ahora pasa a formularse en clave anticomunista: según esta, las fuerzas mal llamadas nacionales no combatieron contra un régimen constitucional y democrático, sino contra el peligro del comunismo y para frenar por anticipado el avance de este en Europa ${ }^{39}$.

Hemos de considerar, por todo ello, que durante el franquismo la causa de la guerra se achacó, desde la cinematografía, a la violencia descontrolada, nefasta y cruel, tanto política como anticlerical de la etapa. No hay duda de que se dio conflictividad y hostilidad social, aunque habría que matizarla, ya que se presenta como si en España la paz social se hubiese resquebrajado por completo y fuera el régimen el único responsable $\mathrm{y}$ no sus diversos actores protagonistas ${ }^{40}$.

Cierto que había cierta base para la propaganda y la exageración (la Sanjurjada, Casas Viejas, Asturias, los terribles actos anticlericales, etc.). Pero a pesar del intento de las autoridades republicanas de mantener el orden social aplicando con dureza la Ley de Defensa de la República, la sensación, mayormente, fue de inseguridad y de que no controlaba la situación ${ }^{41}$. Claro que las cifras no conducen a considerar que

\footnotetext{
39 Heredero, 1993, p. 204.

40 Aróstegui, González Calleja y Souto, 2000 y Ledesma Vera, Muñoz Soro y Rodrigo, 2005.

41 González Calleja, 2015 b.
} 
hubo un desorden social y anarquía. Las conclusiones a las que llega González Calleja a este respecto afirman lo contrario, no se dio una «violencia prerrevolucionaria organizada por la extrema izquierda para conquistar el poder», ni tampoco un "predominio de los usos paramilitares en la actuación contrarrevolucionaria de la extrema derecha ${ }^{42}$. Y sentencia que la violencia por si sola no fue la que destruyó la democracia republicana.

Sin embargo, todas las películas señaladas configuraron parte del mito que favoreció los intereses de la derecha que explotaron a través de los medios esa violencia política y anticlerical, y que acabó por impregnar el imaginario social ${ }^{43}$.

Si bien, eso no quiere decir que la República fuera blanda en sus actuaciones ni que todas las situaciones dramáticas respondieran a una pugna política únicamente cerrada en derecha versus izquierda. Pues «la conflictividad y la violencia en la República no tuvieron como exclusivo motor las luchas políticas o ideológicas ${ }^{44}$, sino que tuvieron que ver con otras sociales que fueron interpretadas como que la República era ingobernable y, por lo tanto, era la hora de los militares ${ }^{45}$.

En efecto, el cine es muy gráfico a la hora de mitificar no solo la necesidad de dar un golpe militar sino de desfigurar la realidad de la violencia para ponerla, en este caso, al servicio del régimen franquista. En definitiva, no se vincula el reformismo republicano ni sus políticas a un intento de desarrollo del país, sino que se caracteriza a la República en un tono perversamente dañino, «abominable» ${ }^{46}$, como causa y responsable única de los hechos que van a conducir a la violencia radicalizada de las izquierdas. Si bien, como puntualiza Viadero, la presencia de personajes republicanos en el cine evolucionará y se les recupera como españoles, aunque se muestre que militan en el bando rojo de forma equívoca ya que, en algunos casos, se arrepienten y redimen en sus actos postreros, siendo el comunista extranjero «el gran enemigo ${ }^{47}$.

El desarrollo del discurso fundamental de tales largometrajes se presenta como que «todo lo que ocurrió en la guerra ya había sucedido an-

42 González Calleja, 2015a, p. 305.

43 González Calleja y Navarro, 2011; González Calleja, 2011a y González Calleja, 2011b, pp. 37-60.

44 González Calleja, 2005, p. 145.

45 Reig Tapia, 1998, p. 221.

46 Duarte, 2013, p. 105.

47 Viadero Carral, 2016, p. 155. 
tes de 1936: revolución social, asesinatos políticos sistemáticos, policías políticas y centros de detención, ejército miliciano, etc.» ${ }^{48}$. Cuando sabemos no solo que no era cierto, sino que el modo de restaurar ese presunto orden social roto vino acompañado por una violencia y una cantidad de muertes peores e indicativamente más elevadas durante la guerra ${ }^{49}$.

\section{La mirada democrática de la violencia republicana}

\subsection{Las distintas violencias: izquierdas versus derechas}

Muerto Franco, se alumbró un nuevo periodo de tiempo, la Transición y, por lo tanto, la revitalización de una nueva memoria, más rica, plural o diversa que ya no venía prefabricada por el Estado o bien controlada por la censura ${ }^{50}$.

Aunque no hay duda de que la violencia comportaba un importante elemento de trauma social implícito en la conciencia de los españoles, más cuando nos referimos a una guerra civil y a la posterior represión, su vínculo con el fin del régimen republicano se presentaba como lo más destacable. En estas condiciones, los filmes ambientados en la Segunda República se enfocan desde diversas perspectivas, unas atienden al contexto político en el que nacieron; otras, en cambio, tienen que ver con la idea que se configura de ese pasado (mayormente como una lección que debemos aprender de sus errores) ${ }^{51}$. Estos dos elementos, contexto y memoria, son claves para entender el perfil de los filmes Retrato de familia (1976), de Antonio Giménez-Rico, y Dragon rapide (1986), de Jaime Camino, sobre la imagen de la violencia durante la República.

El primero que trata este periodo es Retrato de familia. Hijo de la Transición, por lo tanto, el discurso que se establece está influido de forma notoria por el hecho de que la sociedad se estaba abriendo a un marco nuevo de entendimiento democrático ${ }^{52}$. Inspirada de forma libre en

48 González Calleja, 2015a, p. 306.

49 Montero y Paz, 2011, pp. 149-197. También en la televisión el franquismo presentó siempre la Segunda República como el antecedente-causa de la guerra.

50 Powell, 2001; Soto, 2005; Tusell, 2007 y Juliá, 2017, pp. 256-265.

51 Caparrós Lera, 1992; Kinder, 1993; y Hernández Ruíz y Pérez Rubio, 2004 y Palacio, 2011.

52 Amell y Garcia (coords.), 1988. 
la novela de Miguel Delibes ${ }^{53}$, la trama se atreve a dar un enfoque muy distinto sobre la problemática española previa a la guerra.

Aunque las intenciones del autor de la novela fueron criticar al maltusianismo a través del devenir de la familia Rubens, la perspectiva que nos ofrece la película es diferente: representa a una tercera España. El contexto temporal que nos ofrece es muy amplio y nos centramos en el previo a la guerra. Se nos muestra a unos personajes arrastrados por las circunstancias. Por lo tanto, el enfoque es presentar otras Españas, en este caso, la neutral. Claro que la violencia, por su impacto, es un elemento que va a destacar en la trama. Se van a presentar varios escenarios de violencia como son el enfrentamiento entre sindicalistas y un grupo de derechistas de la CEDA, al inicio, y tres atentados terroristas (contra un socialista, un comerciante de derechas y, finalmente, otro dirigido contra el propio negocio de los Rubens), todos ellos en el periodo del Frente Popular. Y al final, como colofón, el propio protagonista se entera del asesinato de Calvo Sotelo que desemboca en altercados e incendios en el campo ${ }^{54}$.

La violencia, por lo tanto, política y social recorre de forma bastante puntual, pero significativa. En esta ocasión, el novedoso modo en el que esta se representa busca repartir responsabilidades, basta indicar el simbolismo de los tres atentados. La violencia política no deja de ser un elemento explicativo del fracaso republicano, y responsabiliza equitativamente a la falta de entendimiento de su propio fracaso.

Habría que aguardar un tiempo hasta volver a encontrarnos con este controvertido tema. Coincidiendo con la conmemoración del $50 .^{\circ}$ aniversario de la guerra se estrenaría Dragon rapide (1986), de Jaime Camino.

El largometraje trata de ilustrar los entresijos políticos y militares, con sus diferencias y tensiones, en julio de 1936, que permitieron el viaje de Franco a Tetuán para encabezar el golpe militar en los territorios africanos. La Segunda República se convierte, en el filme, en un telón de fondo frente a la trama golpista, aunque es descrita por los conspiradores como un régimen que «solo sabe quemar iglesias» e incapaz de mantener el orden. Aunque no se muestran imágenes directas de ninguno de tales hechos, salvo cuando se alude al asesinato del teniente Castillo y se produce

53 Delibes, 1986.

${ }^{54}$ González Calleja, 2015a, p. 307. Pero, aunque es cierto que este periodo fue el más sangriento de la historia democrática (solo superado por el de 1934), eso no evita pensar que también hubo otros intensamente truculentos. 
la detención de Calvo Sotelo, sí desvela la visión de los militares que consideraron que la patria estaba abocada al abismo de la anarquía si no actuaban pronto ${ }^{55}$.

Aunque Camino no muestra una República llena de violencias, tampoco matiza que fue una exageración que benefició a la propaganda de la derecha.

Tres décadas más tarde, la visión que se ofrece de la violencia en el periodo tomaba, paradójicamente, otro cariz. La película Pasiones rotas (1995), de Nick Hamm, fue una producción de carácter internacional que, a pesar de su elenco de estrellas (Polly Walker, Vincent Pérez, Franco Nero o Francisco Rabal), pasó desapercibida por las carteleras, debido a su mediocridad artística. La historia transcurre en Asturias, en 1936, aunque se inspira en una novela de la escritora Kate O'Brien, ambientada en Portugalete (Vizcaya) en los años $20^{56}$. Este curioso cambio de contexto acabaría por mostrar una visión de la República en Asturias no solo desenfocada sino torpe y contradictoria. Aunque el largometraje se pronuncia como un alegato anti-fascista, no lo hace de forma convincente. De hecho, muestra una visión mitificada de la seducción que tienen los españoles por la sangre, que se ve ilustrada en el simbolismo de una corrida de toros ${ }^{57}$.

A partir de ahí, se nos describe un confuso escenario plagado de tópicos, con violencia y altercados entre las fuerzas del orden y grupos de manifestantes de izquierdas sin identificar, que acaban en un baño de sangre en Madrid.

La causa de este enfrentamiento no viene, en ningún caso, explicada, lo cual parece mostrarnos una sociedad en la que el enfrentamiento ideológico entre izquierdas y derechas se encontraba a la orden del día. La película reproduce una mirada tópica de la casuística de la guerra, con su cariz de leyenda negra, a la que, sin reproducir el mito franquista de una sociedad rota y dividida entre fascistas y comunistas, se asemeja. Claro que aquí se le da la vuelta, convirtiendo a los fascistas manidamente en los malos, y a los buenos se identifica con las izquierdas. En otras palabras, no solo no parecía que hubiese evolucionado la presentación de su

55 Crusells, 2006, pp. 275-278.

56 O'Brien, 1990.

57 Véase, Crow, 2005, p. 433 y Núñez Florencio, 2013, pp. 433-463. El cine español además había explotado este gusto por la fiesta nacional: Viadero Carral, 2016, pp. $317-$ 321. 
marcada turbulencia social y política, sino que daba, incluso, pie a considerar que las tesis revisionistas tenían razón y que la época se había visto caracterizada única y exclusivamente por la confrontación sistemática ${ }^{58}$.

\subsection{Un mundo con tensiones sociales pero sin violencia}

El siguiente bloque de películas va a destacar, curiosamente, porque el retrato que se realiza de la época republicana, en contraste con el anterior, es prácticamente de una notoria ausencia de violencia. Así, volviendo a algunas cintas ya mencionadas, en este apartado destacan los filmes $\mathrm{Mi}$ hija Hildegart (1977), Tierra de rastrojos (1979), La plaza del diamante (1982), Réquiem por un campesino español (1986), La lengua de las mariposas (1999), El lápiz del carpintero (2003) y La buena nueva (2008).

Una película de la Transición será Mi hija Hildegart (1977), quien se encarga tan solo de mostrarnos el desencanto con la República y sirve de advertencia para desautorizar los fanatismos. El periodo democrático es descrito como una oportunidad para la política y el debate, para ensalzar la liberación de la mujer, aunque con trágicas consecuencias para las protagonistas, pero sin abordar otros temas del contexto.

En La plaza del diamante (1982) la alusión al marco republicano es bastante breve, se define la situación política como de grave («la situación empeora»), aunque no se ilustra el motivo ni hay ninguna explicación sobre por qué está así. Pero, en todo caso, no se produce ningún altercado serio en la vida de los protagonistas.

Mientras, en Tierra de rastrojos (1979), donde se radiografía la dura vida campesina, se verá como mejorará durante el periodo republicano, gracias a las reformas emprendidas. Todo este proceso se lleva a cabo de forma ordenada, sin enfrentamientos contra la autoridad, y mostrando que los campesinos hacen prevalecer sus derechos para trabajar, no ya al albur de los señores y capataces, como sucedía antes. Si bien, tales logros reformistas quedan rotos abruptamente por el inicio de la guerra y la persecución despiadada de los campesinos por parte de los falangistas.

En Réquiem por un campesino español (1985), por su parte, la instauración republicana también provocará cambios en la autoridad local, lo que permite que se puedan emprender reformas y trabajar las tierras que

58 Reig Tapia, 2006b. 
el señor duque mantiene improductivas. Para impedir que los campesinos puedan ocuparlas, en un momento dado, varios guardias armados serán contratados por el administrador del duque, pero Antonio, el protagonista, tras dialogar con ellos, acabará por convencerles de los beneficios que van a acarrear tales cambios y bajarán sus armas y se les sumarán.

En ambas películas, ambientadas en zona agraria, la resolución del enfrentamiento social se resuelve de forma pacífica o, por lo menos, no se desvela ningún incidente durante la etapa democrática. Es verdad que «entre los campesinos pobres el cambio institucional y político venía a representar sus expectativas de progreso social y económico» ${ }^{59}$, pero por eso el campo español vivió una época muy agitada, aunque no fue debido a la debilidad republicana, ya que las fuerzas de seguridad actuaron duramente (Castilblanco, Arnedo o Casas Viejas). No fue, en suma, un marco tan ideal como se vislumbra en estos filmes, aunque tampoco, como se pensó en la posguerra, fue el preámbulo al estallido de una revolución social ${ }^{60}$.

En los siguientes filmes La lengua de las mariposas (1999), de José Luis Cuerda, El lápiz del carpintero (2003), de Antón Reixa, y La buena nueva (2008), de Helena Taberna, que se ambientan en 1936, los dos primeros en Galicia y el último en Navarra, tampoco hay violencias explícitas dignas de destacar.

Aunque de los tres, solo el primero se desarrolla por completo en el quinquenio republicano y en los otros la época ocupa muy poco tiempo del metraje.

En ellos, la República queda mayormente perfilada como un periodo tranquilo y pacífico, no exento de tensiones (aunque no dedica mucho metraje a explorarlas y bucear en sus rasgos, salvo en el filme de Cuerda) entre reformistas y conservadores, entre modernidad y tradición, laicismo y clericalismo. Toda esa violencia política y social, frente a las muestras que se han visto del apartado anterior, no aparecen evidenciadas de una forma tan nítida, lo cual convierte el marco en un contexto en cierto modo idealizado, que solo se ve roto, sacando a relucir todos los odios y rencores, tras la inmediata sublevación militar. La cruel y vengativa represión salvaje ejercida por el bando sublevado una vez comienza la contienda, o tras ella, desvelará una realidad quebrada por el fanatismo, mayormente vinculado con la derecha ultraconservadora.

59 Tébar Hurtado, 2006, p. 78.

${ }^{60}$ Malefakis, 1972. 


\subsection{La violencia anticlerical durante la República}

A partir de 1999, debido al cada vez mayor interés por el proceso de recuperación de la memoria histórica, fueron impulsadas distintas producciones que se centraron en perfilar, esencialmente, la dura represión franquista, aunque también se producirían otros largometrajes que harían referencia a la controvertida violencia anticlerical durante el marco republicano. Pues si hubo un aspecto que iba a sobresalir y crear conflictos de consideración fueron las políticas laicistas de la Segunda República. En ellas faltó un entendimiento mayor con la Iglesia y una sensibilización adecuada con los amplios sectores de la sociedad española creyentes. La nueva legislación aprobada se interpretó como un ataque directo a la fe católica y a eso se añadieron diferentes momentos en los que la República no supo atajar de forma conveniente un marcado anticlericalismo, como los hechos sucedidos en mayo de 1931 y en marzo de $1936^{61}$.

El cine franquista se aprovechó de ello para convertirlo en un instrumento de propaganda muy importante y, así, considerar que la República y las izquierdas eran enemigos de la patria. De ahí que surgiera el mito de la cruzada española, en defensa del catolicismo contra el terror comunista, visto el brutal asesinato de religiosos que se dio en los meses siguientes a la sublevación militar ${ }^{62}$.

Sin duda, en este nuevo periodo democrático, la lectura que se ofrece sobre la cuestión religiosa está más matizada que en los filmes de épocas precedentes.

En La lengua de las mariposas (1999), se tratará muy brevemente la cuestión religiosa. En sus escenas iniciales se nos muestra a varias vecinas comentando el efecto que han tenido los actos anticlericales en Madrid, en la primavera del 36. Si bien, se hace una defensa del ideario republicano, cuando Rosa, la madre de Moncho, el niño protagonista, esgrime el siguiente alegato: «Los republicanos no queman iglesias». El mismo maestro protagonista, don Gregorio, y el sacerdote, aunque no son afines, dialogan y se respetan. Se lanza un mensaje conciliador, aunque evita adentrarse más a fondo en la tensión que las políticas laicistas republicanas (acompañadas de brotes iconoclastas) generaron en la sociedad española.

\footnotetext{
61 Martí Gilabert, 1998 y La Parra y López y Suárez Cortina 1998.

${ }^{62}$ Cárcel Orti, 1990 y Albertí, 2008.
} 
La película que intentaría más directamente enfocar la cuestión como causa del origen de la contienda fue la fallida Visionarios (2001), de Manuel Gutiérrez Aragón. Inspirada libremente en un suceso verídico, la supuesta aparición de la Virgen, en Ezkioga ${ }^{63}$, representa el choque que se dio en el marco del País Vasco entre quienes propugnaron la aplicación de las nuevas leyes y los creyentes católicos. Aunque el largometraje, según su director ${ }^{64}$, pretendía ser una denuncia de los fanatismos, en realidad, la poco coherente y creíble trama no es capaz de reproducir con éxito esta cuestión, mostrando a unas autoridades republicanas comprensivas y a unos sectores conservadores intransigentes, que utilizan el fervor religioso de la gente para crear las condiciones para impulsar su golpe militar. La historia, lejos de radiografiar, además, con acierto la situación social se convierte en un drama de escasa entidad. Aunque sí deja patente los actos anticlericales, como la destrucción de iconos religiosos, atentados contra la autoridad y, finalmente, el asesinato de un maestro laico.

La siguiente película con la que nos encontramos, que describe el clima religioso republicano, aunque muy brevemente, sería La buena nueva (2008), en la que se señala tensión social en el País Vasco por este motivo. Sin embargo, no se explican los motivos concretos, siendo su intención el denunciar la represión franquista en Navarra, todo ello contado desde la singularidad del punto de vista de un joven sacerdote.

Tres años más tarde, se llevaría a la gran pantalla la biografía del fundador del Opus Dei, José María Escrivá de Balaguer, Encontrarás dragones (2011), de Roland Joffé. Si bien la mayor parte del largometraje se desarrolla antes y durante la guerra, hay dos momentos singulares que se ambientan al final del periodo. En uno de ellos se muestra el rapto y el asesinato de un líder sindicalista por militares y derechistas (lo que sintetiza el pistolerismo reinante) y en otro aparece el entonces joven sacerdote, que ve como la iglesia en la que se encuentra orando es asaltada por una turba exaltada de milicianos. José María huye, en última instancia, cogiendo un icono religioso para salvarlo de la destrucción, aun a riesgo de su vida.

Una vez más, esos detalles identifican dos aspectos sobre la conflictividad y el anticlericalismo reinantes, sin embargo, no se explica su origen

${ }^{63}$ Christian, 1997.

64 García, 2001. 
ni se identifica a los provocadores, lo cual ofrece una visión simplista. Aunque es verdad que contrapone la intolerancia de unos, la ultraderecha (contra los sindicalistas y la República, a la que se califica de «manzana podrida»), frente a los otros, la izquierda radical, como causas de la confrontación bélica posterior. Y pone de relieve que la violencia de la extrema derecha fue mucho más brutal, evitando así sacar a colación únicamente solo los actos anticlericales, para apelar con ello a una mirada reconciliadora ${ }^{65}$.

Con todo, parece que esta pugna social y política en las calles es la responsable directa de que sucediera la Guerra Civil, cuando esta exagerada visión benefició la reacción contrarrevolucionaria de los militares. No debemos pasar por alto que la sociedad española se había polarizado solo en apariencia, ya que entre los grupos de derechas y de izquierdas había una pluralidad de visiones y actitudes ${ }^{66}$.

Las lecturas más recientes son del director Pablo Moreno, y se trata de los filmes Un dios prohibido (2013) y Poveda (2016), ambos los podemos definir como de cine religioso, que se inspira también en hechos reales. Sin duda, surgen al calor de lo que Ferro denominaría «contra-historia» ${ }^{67}$, frente a la historia oficial (Ley de Memoria Histórica), al recordarnos la violencia anticlerical republicana.

En Un dios prohibido (2013) se retrata la suerte aciaga de los seminaristas claretianos asesinados en Barbastro, a inicios de la Guerra Civil. El filme arranca poco tiempo antes del inicio del golpe militar. Los jóvenes religiosos se nos presentan campechanos y entusiastas. Pero nada más llegar a Barbastro, el hermano superior les da la bienvenida y les explica que han sido trasladados por las «circunstancias políticas», porque allí las gentes les quieren y porque el ejército garantiza «el orden y los derechos que aún nos quedan en esta República». Y recalca que ellos son gente de paz y que su labor son las misiones y ayudar a los pobres. El asesinato de Calvo Sotelo, un símbolo muy recurrente, se anuncia en la historia como «los funerales de la democracia». Al poco, arranca la guerra que supone el control de la localidad por parte de milicianos que acabarán ajusticiando a los religiosos. tico.

${ }^{65}$ Hecho que no gustó en ciertos blogs de ultraderecha y conservadurismo eclesiás-

66 Todo ello, claro está, influido por el contexto europeo y los efectos de la Gran Guerra. Cf. Gerwarth, 2017 y Del Rey y Álvarez Tardío, 2017.

67 Ferro, 1995, p. 17. 
Poveda (2016), por su parte, retrata la vida del padre Pedro Poveda a lo largo del primer cuarto del siglo Xx, impulsor del Instituto Teresiano, para educar a futuras maestras católicas, hasta su asesinato en Madrid en julio de 1936.

El filme tiene como ingrediente esencial ser un alegato en favor de la importancia de la educación católica en España. Es verdad que el interés de la historia no es caracterizar el contexto republicano. No solo es breve, sino que está sintetizado con equívocos clichés. En una secuencia, se escucha la famosa frase de Azaña, «España ha dejado de ser católica», resumiendo el anticlericalismo reinante, $\mathrm{y}$ en la siguiente un individuo descerraja a otro un tiro sin saber muy bien por qué, como síntesis de lo que implicó el pistolerismo. Cierto es que el personaje de Poveda, hay que puntualizar, no se muestra antirrepublicano. Al contrario, rechaza el odio y aboga por la paz y la mesura. Pero se vuelve a vincular a esta época con la violencia política, como si fuese la única en España que se hubiese dado con tanta fuerza y mistificación.

Por todo ello, la imagen que se recoge de la época republicana adquiere una connotación funesta, con una República en donde emergieron sectores tremendamente intransigentes y violentos anticatólicos. Cierto que las intenciones de ambos filmes no son tanto desacreditar al régimen, como desmontar los tópicos de una Iglesia ajena a los males que aquejaban al país y establecer que no estuvo, ni mucho menos, comprometida con las corrientes fascistas, sino que fue respetuosa con el gobierno democrático.

Tales filmes, en suma, tratan de restaurar la memoria de aquellos hombres que pugnaron contra un mundo hostil a la fe católica en su misión evangelizadora y cristiana; frente a un cine dominante, el de la represión franquista, nacido al calor de las políticas de la recuperación de la memoria, que solo mostraba un lado [el nacional], y sus matanzas, dejando sin señalizar las que se dieron en la parte republicana.

\section{Conclusión}

Tratar de explicar cuáles fueron los elementos que causaron la imposibilidad de que la Segunda República pudiera afianzarse en España es muy complejo y, por supuesto, más difícil perfilarlo en el cine. Actualmente, gracias a la historiografía académica, poseemos un rico, matizado y certero retrato del intenso, complejo y decisivo quinquenio republicano, 
aunque sabemos que ninguna de estas conflictividades (ya existentes antes) fue susceptible de provocar la tremenda quiebra social, salvo la opción golpista que se convertiría, ante los hechos, en el peor de los remedios posibles.

Sin embargo, en la cuestión del imaginario, el cine ha contribuido dando pie a consolidar ciertos mitos o prejuicios confusionistas. En los diferentes apartados se ha ido valorando la evolución en la caracterización, por parte de la cinematografía franquista, de la transición y la democracia del retrato que llevan a cabo del clima y tiempos republicanos. Su advenimiento se ha dibujado de forma muy desigual.

Fue recibida y aceptada de forma pacífica, hasta el franquismo lo representaría de este modo, si bien, acomodándolo a su visión de un tiempo que anticipaba una guerra inevitable, por encarnar todos los males del país.

Para el cine de la transición-democracia, mayormente, se ilustra como un marco de ilusión y de esperanzas fallidas, salvo en el filme anarquista Borrasca, aunque sin ahondar en las causas que derivaron en su traumático y terrible final.

En cuanto a la caracterización del periodo en sí mismo, las visiones que nos ofrece el franquismo y la transición-democracia son diametralmente opuestas.

La visión franquista se encargó de fijar en la retina del espectador la época republicana como un periodo de corrupción, desorden, violencia callejera y anticlerical y caos político, casi como un prólogo de la misma Guerra Civil (desde Gracia y Justicia, Raza a Un puente sobre el tiempo), sin redención posible. Todas ellas etiquetas condenatorias, que fueron sostenidas, con ciertas variantes, hasta el final.

Con la reinstauración de las libertades constitucionales, la visión democrática ofrecerá otros discursos más plurales (aunque no necesariamente más veraces) que, como se han ido viendo, van desde el reparto de culpas sobre las distintas violencias de derechas e izquierdas (Retrato de familia) a advertir sobre el fanatismo (Mi hija Hildegart), que refleja el ambiente conciliatorio de la Transición; pasando a verlo como un periodo de tensiones, pero sin violencia, idealizado (La lengua de las mariposas), quebrado únicamente por la sublevación militar o la violencia derechista (Pasiones rotas); hasta llegar a otro más reciente, (coincidiendo con las nuevas políticas públicas sobre la memoria) en el que se vuelve a enfatizar la intolerancia y la violencia anticlerical (Visionarios, Pasiones Rotas o Poveda), como elemento más representativo. 
Claro que ninguna de ellas da el paso para ofrecer una visión integradora o adecuadamente matizada, quedando la República como un marco excepcional de violencia, en el mejor de los casos compartida, o de oportunidades perdidas (cuya responsabilidad de su fracaso se adjudica, ante todo, al rancio ultraconservadurismo). Además, sorprende la falta de atención dada en el cine de la democracia a los temas relacionados con la emergencia de los nacionalismos periféricos (catalán, vasco y gallego), prácticamente, con menciones anecdóticas a los distintos estatutos.

Sin duda, hay que tener muy en cuenta el enorme peso traumático, o influencia, derivado de la Guerra Civil, y el configurar una memoria cinematográfica republicana expurgada de mitos y falsedades, más certera, adecuada y/o consensuada, alejada de los prejuicios ideológicos, recelos o endebles lecturas, a pesar de los avances de la ciencia histórica a este respecto, no ha sido posible. Y así, como se ha ido viendo, se ha dado como resultado un perfil deslavazado del marco republicano, con demasiadas películas, por no decir la mayoría, que se refieren al periodo más como un escenario en el que enmarcar las tramas, que por ocuparse centralmente de la cuestión, sin adentrarse o interesarse por caracterizar con cierto rigor (ejemplarizante) la época, en la que la violencia (sea política, social o anticlerical) ha determinado o influido (incluso en la ausencia de esta), junto al contexto de producción, la visión que se ha ofrecido de ella, dando lugar a un triángulo de las Bermudas, entre lo maldito, lo turbulento o lo idealizado.

Claro que tales aspectos vienen imbricados directamente en lo que cada filme es capaz de transmitirnos o sugerirnos, y nosotros aceptamos y hacemos nuestro como espectadores, teniendo en cuenta sus calidades artísticas o su buena o mala recepción, dos elementos a tener en cuenta.

En este caso, habiéndome centrado en el discurso fílmico principalmente, la imagen de la Segunda República ha quedado recogida e identificada en el cine de ficción, sobre todo, como el retrato manifiesto de aquellas dos Españas enfrentadas y, aparentemente, irreconciliables, y cuya memoria conflictiva nos está resultando tan difícil de casar con la Historia y su singularidad reformadora, incluso actualmente.

\section{Bibliografía}

Aguado, Ana y Ramos, M. ${ }^{a}$ Dolores, La modernización de España (1917-1939), Editorial Síntesis, Madrid, 2002. 
Igor Barrenetxea Marañón

Aguilar Fernández, Paloma, Memoria y olvido de la Guerra Civil española, Alianza, Madrid, 1996.

Álvarez Tardío, Manuel y Villa García, Roberto, El precio de la exclusión. La política durante la Segunda República, Encuentro, Madrid, 2010.

Álvarez TARdío, Manuel y Del Rey, Fernando (eds.), El laberinto republicano. La democracia española y sus enemigos (1931-1936), RBA, Barcelona, 2012.

Álvarez Tardío, Manuel y Villa García, Roberto, 1936. Fraude y violencia en las elecciones del Frente Popular, Espasa, Barcelona, 2017.

AlberTí, Jordi, La Iglesia en llamas, Destino, Barcelona, 2008.

Alzola Cerero, Pablo, «Vanguardia cinematográfica y disensión política en Rojo y Negro», Film-Historia, núm. 1, 2017, pp. 39-52.

Amell, Samuel y García, Salvador (coords.), Diez años de cine, cultura y literatura (1975-1985), Playor, Madrid, 1988.

Aróstegui, Julio, González Calleja, Eduardo y Souto, Sandra, «La violencia política en la España del siglo XX», en Cuadernos de Historia Contemporánea, núm. 22, 2000, pp. 53-94.

Ballarín, Manuel y Ledesma, José Luis (eds.), Avenida de la República, Cortes de Aragón, Zaragoza, 2007.

Ben Ami, Sholomo, Los orígenes de la Segunda República española. Anatomía de una transición, Alianza, Madrid, 1990.

Blas, Andrés de, El socialismo radical en la II República, Túcar, Madrid, 1978.

Box, Zira, España, año cero, Alianza, Madrid, 2010.

Burke, Peter, Visto y no visto. EL uso de la imagen como documento histórico, Crítica, Barcelona, 2001.

CAMARero, Gloria (ed.), La mirada que habla (cine e ideologías), Akal / Comunicación, Madrid, 2002.

CAMPORESI, Valeria, Para grandes y chicos. Un cine para los españoles 19401990, Ediciones Turfan, Madrid, 1994.

CAPARRós LeRA, José María, El cine español bajo el régimen de Franco (19361975), Publicaciones de la Universidad, Barcelona, 1983.

CAPARrós Lera, José María, El cine español de la democracia, Anthropos, Barcelona, 1992.

CARCEl ORTI, Vicente, La persecución religiosa en España durante la Segunda República (1931-1939), Rialt, Madrid, 1990.

CAstro, Luís, Héroes y caídos, Catarata, Madrid, 2008.

CAstro de Paz, José Luis, Un cinema herido, Paidós, Barcelona, 2002.

CAzorla SÁnchez, Antonio, Las políticas de la victoria, Marcial Pons, Madrid, 2000.

Christian, William A. Jr., Las visiones de Ezkioga. La Segunda República y el Reino de Cristo, Ariel, Barcelona, 1997.

CONTRERAs, Manuel, El PSOE en la II República: Organización e ideología, CIS, Madrid, 1981. 
La «niña bonita». Imágenes de la violencia (y no violencia) de la Segunda República ...

Crow, John A., Spain. The Root and the Flower: An Interpretation of Spain and the Spanish People, Berkeley, University of California, 2005.

CRusells, Magí, Cine y guerra civil española. Imágenes para la memoria, Ediciones JC, Madrid, 2006.

CRuz, Rafael, El Partido Comunista de España en la II República, Alianza, Madrid, 1987.

CRUZ, Rafael, En el nombre del pueblo, Siglo XXI, Madrid, 2006.

CRUZ, Rafael, Una revolución elegante. España 1931, Alianza, Madrid, 2014.

Cuesta, Josefina, La odisea de la memoria, Alianza, Madrid, 2008.

De GuZMÁn, Eduardo, Aurora de sangre, Rollán, Madrid, 1956.

Del Rey, Fernando (coord.), Palabras como puños. La intransigencia política en la Segunda República española, Tecnos, Madrid, 2011.

Del Rey, Fernando y Álvarez Tardío, Manuel (dirs.), Políticas del odio: violencia y crisis en las democracias de entreguerras, Tecnos, Madrid, 2017.

DeliBes, Miguel, Mi idolatrado hijo Sisí, Círculo de lectores, Barcelona, 1986.

Espinosa, Francisco (ed.), Violencia Roja y Azul. España 1936-1959, Crítica, Barcelona, 2010.

DuARTE, Ángel, «La República, o España liberada de sí misma», en Moreno LaGnY, Michele, Cine e historia, Bosch, Barcelona, 1997.

LuZÓn, Javier y NúÑEZ SEIXAS, Xosé M. (eds.), Ser españoles. Imaginarios nacionalistas del siglo XX, RBA, Barcelona, 2013, pp.104-132.

Egido León, Ángeles (ed.), Memoria de la Segunda República. Mito y Realidad, Biblioteca Nueva, Madrid, 2006.

ElEnA, Alberto, «¿Quién prohibió Rojo y Negro?», Secuencias, n. ${ }^{\circ}$ 7, 1997, pp. 61-78.

Fentress, James y WiCKHAM, Chris, Memoria social, Frónesis, Madrid, 2003.

FERRO, Marc, Historia contemporánea y cine, Ariel, Barcelona, 1995.

GARCíA, Rocío, «El fanatismo no sólo provoca la destrucción de los demás, también la de los fanáticos», El País, 23 de septiembre de 2001.

Gerwarth, Robert, Los vencidos. Por qué la Primera Guerra Mundial no concluyó del todo (1017-1923), Galaxia Gutenberg, Barcelona, 2017.

Gil Pecharromán, Julio, Historia de la Segunda República española (19311936), Biblioteca Nueva, Madrid, 2002.

Gil Pecharromán, Julio, Con permiso de la autoridad. La España de Franco (1939-1945), Temas de Hoy, Madrid, 2008.

GonzÁlez CALleja, Eduardo, «La dialéctica de las pistolas: la violencia y la fragmentación del poder político durante la Segunda República», en LEDESMA Vera, José Luis, MuÑoz Soro, Javier y Rodrigo, Javier (coord.), Culturas y políticas de la violencia. España siglo XX, Siete Mares, Madrid, 2005, pp. 101-146.

González Calleja, Eduardo y Navarro, Rocío (eds.), La España del Frente Popular, Comares, Madrid, 2011. 
Igor Barrenetxea Marañón

González Calleja, Eduardo, Contrarrevolucionarios, Alianza, Madrid, 2011a.

GonZÁlez CALlEJA, Eduardo, «La necrológica de la violencia sociopolítica en la primavera de 1936», Mélanges de la Casa de Velázquez. [En ligne], 41-1 I 2011, mis en ligne le 15 avril 2013, consulté le 10 juillet 2011b, pp. 37-60.

GonzÁlez CAlleja, Eduardo, Cifras cruentas. Las víctimas de la violencia sociopolítica en la Segunda República española (1931-1936), Comares, Granada, 2015a.

GonzÁlez CAlleja, Eduardo, En nombre de la autoridad. La defensa del orden público durante la Segunda República española (1931-1936), Comares, Granada, 2015b.

González Calleja, Eduardo, Cobo Romero, Francisco, Martínez Rus, Ana y Sánchez PÉrez, Francisco, La Segunda República española, Pasado\&Presente, Barcelona, 2015.

GonZÁlez CAlleja, Eduardo y RiBAgORda, Álvaro, (eds.), Luces y sombras del 14 de abril. La historiografía sobre la Segunda República española, Biblioteca Nueva, Madrid, 2017.

GUBERN, Román, «Raza: un film-modelo para un género frustrado», Revista de Occidente, núm. 85, 1985, pp. 61-75.

GubERn, Román et al., Historia del cine español, Cátedra, Madrid, 2015.

Halbwachs, Maurice, La memoria colectiva, Prensas Universitarias de Zaragoza, Zaragoza, 2004.

Heredero, Carlos F., Las huellas del tiempo. Cine español 1951-1961, Ed. Documentos Filmoteca, Valencia, 1993.

Hernández Ruiz, Javier y Pérez Rubio, Pablo, Voces en la niebla. El cine durante la transición española (1973-1982), Paidós, Barcelona, 2004.

Holguín, Sandie, República de Ciudadanos, Crítica, Barcelona, 2003.

Juliá, Santos, La izquierda del PSOE, Siglo XXI, Madrid, 1977.

Juliá, Santos, Historias de las dos Españas, Taurus, Madrid, 2005.

Juliá, Santos (dir.), Memoria de la guerra y del franquismo, Taurus, Madrid, 2006.

Juliá, Santos, Transición. Historia de una política española (1937-2017), Galaxia Gutenberg, Barcelona, 2017.

KINDER, Marsha, Bood Cinema. The reconstruction of national identity in Spain, University Of California Press Berkeley, Berkeley, 1993.

La PARra, Emilio y LóPez y SuÁrez Cortina, Manuel (eds.), El anticlericalismo español contemporáneo, Biblioteca Nueva, Madrid, 1998.

Ledesma Vera, José Luis, MuÑoz Soro, Javier y Rodrigo, Javier (coord.), Culturas y políticas de la violencia. España siglo XX, Siete Mares, Madrid, 2005.

MACARro, José Manuel, «Los socialistas y la revolución», en Manuel Álvarez Tardío y Fernando Del Rey (eds.), El laberinto republicano, RBA, Barcelona, 2012, pp. 75-100.

MALEFAKIS, Edward, Reforma agraria y revolución campesina en la España del siglo XX, Ariel, Barcelona, 1972. 
La «niña bonita». Imágenes de la violencia (y no violencia) de la Segunda República ...

Martí Gilabert, Francisco, Política religiosa de la Segunda República española, EUNSA, Pamplona, 1998.

MirAmBel, Miquel, «Barcelona y La plaza del Diamante», Film-Historia, núm. 3, 1994, pp. 1-10.

Mainer, José-Carlos y Juliá, Santos, El aprendizaje de la libertad 1973-1986, Alianza, Madrid, 2000.

Montero, Julio, y PAZ, María Antonia (coord.), Historia y cine, Editorial Complutense, Madrid, 1995.

Montero, Julio, y PAz, María Antonia, «The Spanish Civil War on Televisión Española during the Franco era (1956-1975), Comunicación y Sociedad, núm. 3, 2011, pp. 149-197.

Montero, Julio, y PAz, María Antonia, «Historia audiovisual para una sociedad audiovisual», Historia Crítica, núm. 49, pp. 159-183.

Moradiellos, Enrique, La España de Franco (1939-1975), Editorial Síntesis, Madrid, 2000.

Moradiellos, Enrique, 1936. Los mitos de la Guerra Civil, Península, Barcelona, 2004.

Morales Muñoz, Manuel (ed.), La Segunda República. Historia y memoria de una experiencia democrática, Diputación de Málaga, Málaga, 2004.

Moreno LuZón, Javier y NúÑEZ SeIXAS, Xosé M., «Rojigualda y sin letra», en Moreno Luzón, Javier y Núñez SeiXas, Xosé M. (eds.), Ser españoles. Imaginarios nacionalistas del siglo XX, RBA, Barcelona, 2013, pp. 57-103.

NúÑEZ FLORENCIO, Rafael, «Los toros, fiesta nacional», en MoRENO LuZÓN, Javier y NÚÑEZ SEIXAS, Xosé M. (eds.), Ser españoles. Imaginarios nacionalistas del siglo XX, 2013, pp. 433-463.

O'Brien, Kate, Mary Lavelle, Edhasa, Barcelona, 1990.

Palacio, Manuel (ed.), El cine y la Transición política en España (1975-1982), Biblioteca Nueva, Madrid, 2011.

Powell, Charles, España en democracia, 1975-2000, Plaza y Janés, Barcelona 2001.

RiCOEUR, Paul, La lectura del tiempo pasado: memoria y olvido, Arrecife, Madrid, 1999.

REES, Tim, «¿Revolución o República? El Partido Comunista de España, 19311936», en Manuel Álvarez Tardío y Fernando Del Rey (eds.), El laberinto republicano, RBA, Barcelona, 2012, pp. 281-306.

REIG TAPIA, Alberto, «La justificación ideológica del Alzamiento de 1936», en Manuel TuÑón de LARA (dir.), La II República española, Siglo XXI, Madrid, 1998, pp. 211-240.

REIG TAPIA, Alberto, «La proclamación de la II República en la memoria literaria y cinematográfica», en Ángeles EgIDo LEÓn (ed.), Memoria de la Segunda República, 2006a, pp. 135-158.

ReIG TAPIA, Alberto, Anti-Moa. La subversión neofranquista de la Historia de España, Editorial B, Barcelona, 2006b. 
Igor Barrenetxea Marañón

Richards, Michael, Historias para después de una guerra, Pasado \& Presente, Barcelona, 2013.

RIQUER, Borja de, La dictadura de Franco, Crítica y Marcial Pons, Barcelona, 2010

Rosenstone, Robert A., El pasado en imágenes, Ariel, Barcelona, 1997.

Rosenstone, Robert A., La historia en el cine. El cine sobre la Historia, Rialp, Madrid, 2014.

Rubio, Ramón, La historia de España a través del cine, Policemo, Madrid, 2007.

SENDER, Ramón J., Réquiem por un campesino español, Destino, Barcelona, 2006.

SÁNCHEZ-BIoscA, Vicente, Cine y guerra civil española del mito a la memoria, Alianza, Madrid, 2006.

Soto, Álvaro, Transición y cambio, Alianza, Madrid, 2005.

TÉBAR HURTADO, Javier, Reforma, revolución y contrarrevolución agrarias, Ediciones Flor del Viento, Barcelona, 2006.

Trenzado, Manuel, Cultura de masas y cambio político: el cine español en la transición, Siglo XXI, Madrid, 1999.

Todorov, Tzvetan, Los abusos de la memoria, Paidós, Barcelona, 2000.

Tusell, Javier, Franco y los católicos: la política interior española entre 19451957, Alianza, Madrid, 1984.

Tusell, Javier, La Transición a la democracia, Espasa, Madrid, 2007.

VIADERO CARRAL, Gabriela, El cine al servicio de la nación (1939-1975), Marcial Pons, Madrid, 2016.

Zunzunegui, Santos, José Luís Castro de Paz y Julio Pérez Perucha (dirs.), La nueva memoria: historias(s) del cine español (1939-2000), Vía Láctea, A Coruña, 2005.

\section{Datos del autor}

Bilbao, 1975. Diplomado en Magisterio (1997), Licenciado (2001) y Doctor en Historia Contemporánea (2014), por la Universidad del País Vasco. Miembro de la Asociación de Historia Contemporánea y la Asociación de Historia Actual, especializado en las relaciones entre cine e historia. Actualmente es profesor de Historia y Geografía en enseñanzas medias. Entre sus múltiples publicaciones en revistas y libros se destacan las más recientes como el artículo « «Más allá de la imagen. El asesinato de Carrero Blanco en la memoria audiovisual», 2016, junto a Santiago de Pablo, "Tata mía (1986) o el espíritu de la Transición», Aportes, 2016 y el libro Memoria, Imagen e Historia. La Segunda República en el cine de ficción (imprenta). Ha intervenido como conferenciante y coordinador de mesas en congresos y jornadas tanto en España como en Reino Unido, Irlanda y Portugal. 
La «niña bonita». Imágenes de la violencia (y no violencia) de la Segunda República ...

\section{Anexo: películas}

\begin{tabular}{|c|c|c|}
\hline Películas (30) & Periodo & Director \\
\hline Gracia y Justicia (1940) & Franquismo & Julián Torremocha \\
\hline Sin novedad en el Alcázar (1940) & Franquismo & Augusto Genina \\
\hline Fortunato $(1941)$ & Franquismo & Fernando Delgado \\
\hline Raza (1942) & Franquismo & José Luís Sáez de Heredia \\
\hline Rojo y negro (1942) & Franquismo & Carlos Arévalo \\
\hline Vida en sombras (1948) & Franquismo & Llobet Gracia \\
\hline El santuario no se rinde (1948) & Franquismo & Arturo Ruiz Castillo \\
\hline Cerca del cielo (1951) & Franquismo & Mariano Pombo y Domingo Viladomat \\
\hline Lo que nunca muere (1954) & Franquismo & Julio Salvador \\
\hline La paz empieza nunca (1960) & Franquismo & León Klimowsky \\
\hline Mi calle $(1960)$ & Franquismo & Edgar Neville \\
\hline Un puente sobre el tiempo (1964) & Franquismo & José Luis Merino \\
\hline Las últimas horas (1965) & Franquismo & Santos Alcocer \\
\hline Pascual Duarte (1975) & Transición & Ricardo Franco \\
\hline Retrato de familia (1976) & Transición & Antonio Giménez-Rico \\
\hline Borrasca $(1977)$ & Transición & Miguel Ángel Rivas \\
\hline Mi hija Hildegart (1977) & Transición & Fernando Fernán Gómez \\
\hline Tierra de rastrojos ((1979) & Transición & Antonio García Cano \\
\hline La plaza del Diamante (1982) & Transición & Francesc Betriu \\
\hline Réquiem por un campesino español (1986) & Democracia & Francesc Betriu \\
\hline Dragon Rapide (1986) & Democracia & Jaime Camino \\
\hline Belle Epoque (1992) & Democracia & Fernando Trueba \\
\hline Pasiones rotas $(1995)$ & Democracia & Nick Hamm \\
\hline La lengua de las mariposas (1999) & Democracia & José Luís Cuerda \\
\hline Visionarios (2001) & Democracia & Manuel Gutiérrez Aragón \\
\hline El lápiz del carpintero (2003) & Democracia & Antón Reixa \\
\hline La buena пиеva (2008) & Democracia & Helena Taberna \\
\hline Encontrarás dragones (2011) & Democracia & Roland Joffé \\
\hline Un dios prohibido (2013) & Democracia & Pablo Moreno \\
\hline Poveda (2016) & Democracia & Pablo Moreno \\
\hline
\end{tabular}

